BANCODEESPAÑA

Eurosistema

\title{
Spanish banks'
}

internationalisation strategy: characteristics and comparison

Isabel Argimón 

SPANISH BANKS' INTERNATIONALISATION STRATEGY: CHARACTERISTICS

AND COMPARISON

\section{Abstract}

Banks' international strategy and the way in which they have expanded are explanatory factors for the economic effects of their activity. Based on information from individual institutions, the internationalisation strategies of banks based in Spain, the Netherlands and the United States have been compared. In addition, in the Spanish case, whether banks' risk, efficiency, return and income source type differ according to the chosen model of internationalisation has been tested. The results of this comparison point to Spanish banks with subsidiaries and branches abroad having higher returns but also higher costs than banks whose foreign business is mainly cross-border.

Keywords: global financial institutions, business models, geographical diversification.

JEL codes: E5, F3, F4, G2. 



\section{SPANISH BANKS' INTERNATIONALISATION STRATEGY: CHARACTERISTICS AND COMPARISON}

Introduction

Comparison of Spanish, Dutch and US banks' internationalisation strategies
Globalisation has been accompanied by a rise in the number of internationally active banking groups. In the pre-crisis period, the presence of foreign banks, whether through branches or subsidiaries, became widespread, with growing geographical coverage. Similarly, cross-border lending expanded, growing faster than trade in goods and services in the early 21 st century (Committee on the Global Financial System, 2010). Although the 2008 financial crisis revealed how, in some cases, international financial groups facilitated the spread of financial tensions, international banks have undoubtedly contributed to growth by providing more financial resources to economic agents and fostering the transfer of good practices and know how. In any event, following the crisis, financial globalisation through banking activity has taken something of a step backwards, with a drop in crossborder activity, particularly in European countries, while that conducted through local affiliates has remained constant and even grown.

Geographical expansion may lead to a bigger assumption of risk by multinational banks if information asymmetry effects predominate. Such asymmetries may arise out of the difficulties distance causes for the parent company's ability to monitor its subsidiaries. However, a bank's expansion can also reduce its risks by diversifying its exposures; which effect predominates is an empirical question. Similarly, banks' presence in multiple countries means that shocks in one country may be transmitted to other jurisdictions through the activity of multinational banks. Specifically, it is possible that there might be monetary policy spillovers, whether inward, where monetary policy in third countries affects lending by banks in the parent bank's home country, or outward, where activity in other countries is affected by changes in monetary policy in the parent bank's country. The model banks follow in their international expansion and internationalisation strategies may be a key factor in explaining the effects on the banking group's risk ${ }^{1}$ and its propensity to mitigate or transmit certain shocks across borders. ${ }^{2}$

This article sets out to analyse some of the distinctive features of the Spanish banking system's international activity, bearing in mind the characteristics of its business model. Following the approach taken by Argimón et al. (2018), using restricted access data on individual institutions, it describes and compares Spanish, Dutch and US banks' internationalisation strategies. Moreover, for the case of Spain it presents the results of a test of the importance of the different internationalisation models in explaining the differences observed between banking groups in terms of risk, profitability, efficiency and revenue source. The results show that multinational and decentralised banks have a lower risk profile, but are also less cost efficient than other Spanish banks.

Banks' internationalisation strategies are defined on various dimensions - the relative importance of foreign business, the way in which this business is organised, the selection of host countries, and choice of a market niche - although in the long term choices along these dimensions are not independent. For example, competing in a given host country's retail market means establishing a local affiliate. These decisions characterise the various models that may be pursued when conducting banking business abroad. This section

1 See Argimón 2017 for an analysis of this relationship using Spanish data.

2 See Argimón et al. (2018) and Argimón (2017) for an analysis of monetary policy spillovers through international banks. 
1 TOTAL FOREIGN LENDING

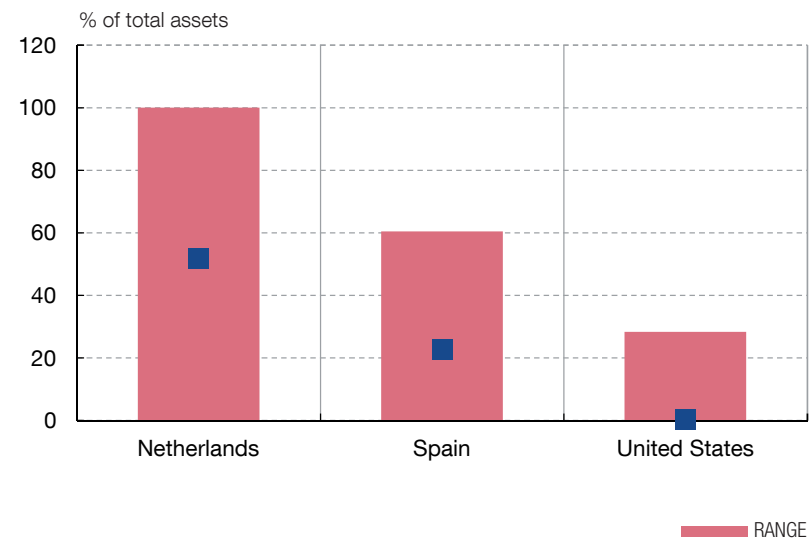

2 NUMBER OF COUNTRIES IN WHICH THE BANK OPERATES

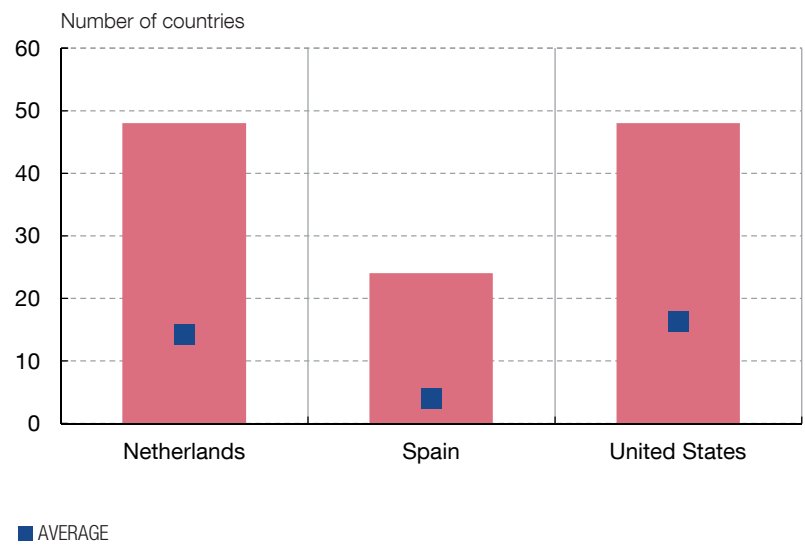

SOURCE: Argimón et al. (2018).

uses the examples of the banking systems in Spain, the Netherlands and the United States to illustrate their different strategies.

The relative importance of external activity differs significantly between the three banking systems analysed, being important for Spanish and Dutch banks, but relatively minor for US banks. According to international statistics reported to the Bank for International Settlements (BIS International Banking Statistics), averaged over the period 2000-15, bank lending to non-residents represents approximately $50 \%$ of Dutch banks' total lending, close to $23 \%$ in the case of Spanish banks and less than $1 \%$ in the case of US banks (see Chart 1.1). The key reasons for these differences are probably the size of the domestic market and its ability to generate profits, although the economic conditions and the regulatory framework in the counterparty country also play a role. For example, the US banking services market is very large, does not appear to be saturated and allows the country's banks to maintain relatively high returns on assets (ECB, 2013).

The organisational structure enabling this foreign business to be conducted may also vary widely, as shown in the cases of the banking systems in the three countries examined. At one end of the scale, Spanish banks tend to be structured around subsidiaries that provide and obtain finance at local level. Their overseas activity is carried out through the consolidated group operating units residing in a specific country with customers from that jurisdiction. In this regard, Spanish banks are pursuing a multinational banking model (McCauley et al., 2010), which is characterised by the predominant role played by subsidiaries, in contrast with the relatively minor role played by cross-border business and that carried out through branches. A branch does not normally have a separate legal personality from its parent. Thus, in principle, through a branch structure, all the assets of the parent bank are available to cover its liabilities in the event of resolution or winding-up, regardless of their geographical distribution. By contrast, a subsidiary is incorporated locally and the parent bank's liability is limited to the capital it holds in it. In principle, subsidiaries have a board of their own and their liquidity and risks are managed independently from the parent. In the subsidiaries model, local assets are funded with 
local liabilities, such that the consolidated group's various operating units have considerable independence over their funding. In other words, each subsidiary is independently funded on the relevant market, mainly through retail deposits. These are often denominated in local currency and protected by the local deposit guarantee scheme, without the explicit support of the parent, thus minimising intra-group financial transactions. Banking groups usually set up legally independent subsidiaries, which often have a significant market share and are directly regulated and supervised by the local authorities. This form of organisation partly responds to the principles of Spanish supervisors, which support financial autonomy for operations abroad, and in the case of expansion in Latin America, the principles of the host country supervisors (Cortina and Fernández de Lis, 2016).

At the other end of the scale, US banks tend to conduct their foreign operations from their head offices and manage their organisations' liquidity internally, such that intra-group transactions are frequent. For its part, the structure of the Dutch banks has changed over time, such that the model lies somewhere between the two extremes. At present, half their foreign activities are carried out from local offices and the other half from the parent (De Nederlandsche Bank, 2015).

The host or counterparty countries are different in the case of the three banking systems and their degree of geographical dispersion also differs. Whereas in the case of Spanish banks foreign activity tends not to be very dispersed, in the case of both the United States and the Netherlands, multinational banks tend to have a presence in a large number of jurisdictions (see Chart 1.2).

The presence of Spanish banks abroad is mainly concentrated in Europe (57\%, notably in the United Kingdom, which accounts for $29.2 \%$ of external lending), Latin America (25.9\%) and the United States with around $14.3 \%$ of external lending. The initial internationalisation of Spanish credit institutions followed the traditional "follow-thecustomer" strategy such that it coincided with the overseas expansion of Spanish nonfinancial corporations. In recent years, foreign expansion has been driven by various processes. On the one hand, growing pressure in the Spanish market from the savings banks, whose business was deregulated in the late 1970s, encouraged the larger banks to expand into less competitive markets, whose level of development pointed to greater growth potential. On the other hand, Spain's joining the European Union pushed Spanish banks "defensively and selectively" (Sierra Fernández, 2007) towards other European countries in the 1990s. Finally, the crisis made it possible to acquire underperforming banks at attractive prices.

For their part, Dutch banks, while still having a generally global presence, have tended to focus on EU markets (De Haan et al., 2015). Lastly, the major US banks tend to be located in the world's biggest financial centres, such as London, Hong Kong or Singapore, whereas there is no clear pattern to foreign business among smaller US banks.

As regards the choice of market niche, to leverage their domestic retail banking experience, Spanish banks usually specialise in providing retail services in their host countries. Activity in this market niche obviously requires banks to operate abroad through physical establishments. By contrast, US banks largely focus their international activity on catering to financial and non-financial corporate clients. In recent decades, US banks have used their capacity to innovate and provide sophisticated corporate products and services to sell them proactively to foreign clients (Venzin, 2009). The major US banks do not need a large number of local establishments to provide these products and services, as they 
Spanish banks' international business models are very heterogeneous, although the large banks take a decentralised multinational approach.

PERCENTAGE OF FINANCIAL ASSETS

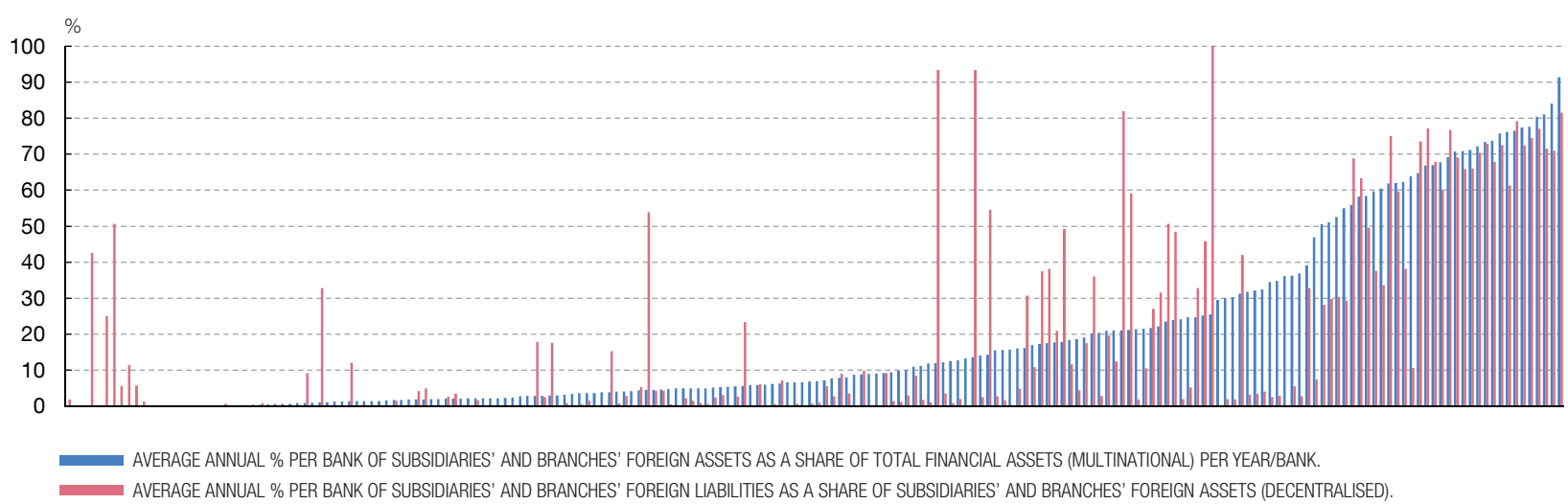

SOURCE: Banco de España.

Characteristics of Spanish banks according to their international business models conduct their foreign business at financial centres remotely from their local offices or the parent bank. Dutch international banks conduct half their foreign business through local affiliates and the other half through the parent. They are highly heterogeneous, such that there is no clear dominant pattern of cross-border activity or of business through subsidiaries and branches (De Nederlandsche Bank, 2015).

In order to test the significance of Spanish banks' different models of internationalisation in explaining the heterogeneity observed between the various banking groups in terms of risk, profitability, efficiency and source of income, it is necessary to first characterise internationalisation strategies precisely. Two dimensions are therefore proposed for the analysis below: the first, referring to banking assets, and the second, to liabilities.

On the assets side, following the terminology of McCauley et al. (2010) and Gambacorta and Van Rixtel (2013), it is possible to distinguish between multinational and international banks. Multinational banks are characterised by a predominance of local entities in the group (whether subsidiaries or branches) in contrast with international banks operating with residents outside the country of origin mainly by conducting cross-border business. This dimension may be proxied by the share of local loans in total lending abroad (multinational). The larger this share and the smaller the emphasis on cross-border business, the closer the bank will be to following a multinational model. Conversely, the smaller this proportion the closer the bank will be to an international model in which business from head office predominates.

On the liabilities side, we intend to use McCauley et al.'s (2010) distinction between centralised and decentralised banks. A centralised bank raises funds at its central offices or head office and redistributes them among the various group entities. Decentralised banks operate in such a way that their foreign affiliates, whether subsidiaries or branches, raise funds to finance their local business locally. Given that the degree of decentralisation is related to the place where the bank raises funds, it can be represented through the total share which financial obligations of subsidiaries and branches abroad account for in total external lending (decentralised). The higher the value of this ratio, the more decentralised the bank, as it is more dependent on local funding. This definition of the degree of 
Banks that follow the decentralised multinational model in their international business show higher non-risk-weighted capital ratios and higher returns, but they have more volatile returns and they are less efficient than banks whose international business is mainly cross-border.

\begin{tabular}{|c|c|c|c|c|c|c|c|c|c|}
\hline \multirow{2}{*}{ Variable } & \multicolumn{4}{|c|}{ Banks with mainly cross-border business (a) } & \multicolumn{4}{|c|}{ Banks with mainly local business (b) } & \multirow{2}{*}{$\begin{array}{l}\text { t-ratio } \\
\text { (c) (d) }\end{array}$} \\
\hline & Average & $\begin{array}{l}\text { Standard } \\
\text { deviation }\end{array}$ & Min. & Max. & Average & $\begin{array}{l}\text { Standard } \\
\text { deviation }\end{array}$ & Min. & Max. & \\
\hline \multicolumn{10}{|l|}{ International business } \\
\hline Decentralised & 0.0 & 0.0 & 0.0 & 0.3 & 63.2 & 11.9 & 27.6 & 81.4 & $188.21^{\star \star \star}$ \\
\hline Multinational & 0.1 & 0.4 & 0.0 & 2.6 & 64.7 & 7.8 & 48.4 & 80.5 & $289.09^{\star \star \star}$ \\
\hline \multicolumn{10}{|l|}{ Financial indicators } \\
\hline $\mathrm{ROA}$ & 0.8 & 0.9 & -15.0 & 8.9 & 3.7 & 3.8 & -2.7 & 23.1 & $21.01^{\star \star *}$ \\
\hline Standard deviation of $\mathrm{ROA}$ & 0.4 & 0.4 & 0.0 & 4.3 & 1.2 & 1.0 & 0.2 & 4.7 & $18.25^{\star \star \star}$ \\
\hline Capital ratio & 6.6 & 2.7 & 0.3 & 20.0 & 14.4 & 9.8 & 3.4 & 39.7 & $21.06^{\star \star \star}$ \\
\hline Size & 11.3 & 1.4 & 7.8 & 16.4 & 12.8 & 2.5 & 8.0 & 16.3 & $9.74^{\star \star \star}$ \\
\hline Efficiency & 1.4 & 0.8 & 0.1 & 7.9 & 2.3 & 1.9 & 1.2 & 9.0 & $9.55^{\star \star \star}$ \\
\hline Share of interest income & 77.4 & 12.1 & 15.8 & 93.4 & 60.3 & 21.6 & 3.0 & 76.2 & $-13.37^{\star \star \star}$ \\
\hline
\end{tabular}

SOURCE: Banco de España.

a Banks with foreign business whose share of local assets and liabilities in their total foreign assets is at the 25th (or lower) percentile.

b Banks with foreign business whose share of local liabilities and assets in total foreign assets is at the 75th (or higher) percentile.

c t-ratio for the contrast of mean differences between banks with mainly cross-border business and banks with mainly local business.

$\mathbf{d}^{* \star *},{ }^{* \star}$ and ${ }^{*}$ indicate statistical significance at the $1 \%, 5 \%$ and $10 \%$ levels, respectively.

decentralisation includes banks with foreign subsidiaries carrying out local business and also those operating through branches.

Although overall the Spanish banking system matches the decentralised multinational model, analysis of the bank-level data shows a high degree of heterogeneity among banks on the two dimensions examined (see Chart 2). Specifically, in over half of all cases, the international presence channelled through subsidiaries and branches is less than $10 \%$ of total assets, and for a similar proportion, liabilities in foreign branches and subsidiaries are less than $5 \%$ of total foreign business. On the other hand, there are banking groups whose foreign business conducted through subsidiaries and branches accounts for more than $50 \%$ of total assets and there are others which receive over a third of their funding from resources obtained abroad in the countries in which their subsidiaries and branches are located.

The different business models defining the way in which Spanish banks have expanded internationally may be associated with the different characteristics of each financial institution. To corroborate this, two groups of banks have been differentiated: banks following the centralised international model, with a large share of cross-border loans and liabilities, and decentralised multinational banks with a large share of local liabilities and loans.

Table 1 shows the average, standard deviation, and minimum and maximum values of a set of financial indicators calculated using Spanish banks' consolidated quarterly data for the period 1999-2014. The two groups of banks are shown separately, and their values for the decentralised and multinational ratios used as proxies for the banks' internationalisation are included. The last column shows the t-ratio comparing the mean differences between 
the characteristics of the group of banks with mainly cross-border business and the group with mainly local business. The financial indicators in the table include the non-riskweighted capital ratio (capital ratio), the average return on assets $(R O A)$ and its standard deviation. The table also includes a size indicator, proxied by the log of total assets (size), an efficiency indicator (efficiency), calculated as the ratio of operating expenses to total assets, and a financial-business diversity indicator (share of interest income) reflecting the ratio of interest income to total interest and fee income.

The figures show that there are statistically significant differences between these two groups of banks. In particular, highly decentralised multinational banks are larger, have higher - albeit more volatile - returns, higher non-risk-weighted capital ratios, lower efficiency and a smaller share of traditional revenue sources than banks whose international business is predominantly cross-border.

10.1.2019

\section{REFERENCES}

ARGIMÓN, I. (2017). Decentralized multinational banks and risk taking: the Spanish experience in the crisis. Banco de España. Working Paper 1749.

ARGIMÓN, I., C. BONNER, R. CORREA, P. DUIJM, J. FROST, J. DE HAAN, L. DE HAAN and V. STEBUNOVS (2018). Financial institutions' business models and the global transmission of monetary policy. Banco de España. Working Paper 1815. Forthcoming in the Journal of International Money and Finance.

COMMITTEE ON THE GLOBAL FINANCIAL SYSTEM (2010). Long-term issues in international banking. CGFS Papers, No. 41.

CORTINA, A. and S. FERNÁNDEZ DE LIS (2016). El modelo de negocio de los bancos españoles en América Latina. BBVA Research, Working Paper No. 16/03.

DE HAAN, J., S. OOSTERLOO and D. SCHOENMAKER (2015). Financial Markets and Institutions: A European Perspective (third edition). Cambridge University Press, Cambridge.

DE NEDERLANDSCHE BANK (2015). Perspective on the structure of the Dutch banking sector. Efficiency and stability through competition and diversity. DNB report, June.

ECB (2013). Banking Structures Report. November.

GAMBACORTA, L. and A. VAN RIXTEL (2013). Structural Bank Regulation Initiatives: Approaches and Implications. BIS Working Paper No. 412.

MCCAULEY, R., P. MCGUIRE and G. VON PETER (2010). The architecture of global banking: from international to multinational? BIS Quarterly Review, March, pp 25-37.

SIERRA FERNÁNDEZ, M. P. (2007). Estrategias de internacionalización de la gran banca española, Revista de la Facultad de Ciencias Económicas y Empresariales. Universidad de León.

VENZIN, M. (2009). Building an International Financial Services Firm. How Successful Firms Design and Execute Cross-Border Strategies. Oxford University Press, Oxford. 